\title{
GENDER DAN PEMBANGUNAN PEREMPUAN DI ACEH PASCA KONFLIK DAN TSUNAMI: PEMBAHASAN TEORITIS
}

\author{
Yeni Sri Lestari \\ Sosiologi, Fakultas Ilmu Sosial dan Ilmu Politik, Universitas Teuku Umar \\ email:yenilestari24@yahoo.com
}

\begin{abstract}
This article discusses the theoretical analysis of gender and its relationship to women's development in post-conflict Aceh and the tsunami. This discussion is considered important because of two causes, first the development of women in most countries is always focused on the gender concepts that discuss the position of men and women from the socio-cultural side that influence development in particular in this study is the development of women's rights Aceh. While the development of women is still minimal has led to demands for the fulfillment of women's rights in Aceh. Based on this, then the issues studied in the discussion of this article are what is meant by gender and how can gender be formed? What is the relationship between gender concepts and women's development process in Aceh?. The findings of the study found that the concept of gender is an important contributor to the birth of women's power in advocating for the development of their rights in post-conflict Aceh and the tsunami. This is because the concept of gender provides a great opportunity for the existing women's movements in various parts of the world, especially in post-conflict Aceh and tsunami in Aceh. At the end of the study, this article shows that gender plays an important role in the development of women's rights in Aceh.
\end{abstract}

Keywords: Gender, Development of women, Aceh, Conflict and Tsunami.

\section{PENDAHULUAN}

Gender dan pembangunan perempuan merupakan kajian yang menarik untuk dibahas secara mendalam. Hal ini dikarenakan kedua pembahasan tersebut telah menciptakan dinamika tersendiri bagi keberlangsungan pembangunan, khususnya di Aceh pasca konflik dan tsunami. Konsep gender sepanjang sejarah telah memperlihatkan keberhasilan dalam menciptakan peluang dan semangat perubahan di kalangan kaum perempuan dalam setiap aspek kehidupan bernegara terutama dalam persoalan pembangunan hak-hak perempuan yang seringkali dinomorduakan setelah laki-laki.

Keberhasilan konsep gender dalam memicu gerakan-gerakan perempuan di beberapa negara menjadi acuan bagi banyak negara, wilayah maupun daerah untuk memperjuangkan hak-hak kaum perempuan. Hal ini seperti yang terdapat di Amerika Serikat dan Inggris yang berhasil memunculkan sebuah gerakan beridentitaskan gender yaitu First Wave Feminism yang terjadi pada 
abad ke-19 dan Second Wave Feminism yang terjadi pada abad ke-20. Di Pakistan, kaum wanita telah berjuang untuk melawan penindasan dari pemerintah semenjak tahun 1947 dan mencapai puncaknya ketika Benazir Bhutto terpilih sebagai perempuan pertama yang berkuasa di Pakistan setelah jatuhnya Zia Ul-Haq pada tahun 1988. Sedangkan di Indonesia, kaum perempuan telah banyak memainkan peran penting dalam pembangunan semenjak masa penjajahan hingga masa reformasi, hal ini ditandai dengan munculnya nama-nama perempuan Indonesia yang berhasil membawa kedudukan perempuan Indonesia menjadi lebih terhormat, seperti jasa R.A Kartini, Laksamana Malahayati, Cut Nyak Dhien dan lain-lain.

Persoalan gender, khususnya di Aceh mulai meluas pasca konflik dan tsunami dilatarbelakangi oleh beberapa faktor. Trauma terhadap konflik yang berkepanjangan (1976-2005) membuat perempuan Aceh mengalami banyak penindasan dan penyelewengan terhadap hak asasi mereka, terutama yang berkaitan dengan harkat dan martabat mereka sebagai perempuan. Tidak sedikit perempuan Aceh menjadi korban penyiksaan dan kekerasan oleh lakilaki pada masa konflik Aceh terjadi bahkan berujung kepada kematian. Selain konflik berkepanjangan, tsunami Aceh pada 26 Desember 2004 semakin memporak-porandakan kehidupan perempuan Aceh secara lahiriah maupun batiniah.

Kesengsaraan dan kesulitan hidup yang selama ini dirasakan oleh perempuan Aceh menjadi acuan bagi kebangkitan perempuan Aceh untuk memperbaiki dan membangun kembali jati diri perempuan Aceh bersamaan dengan terjadinya kesepakatan damai antara pemerintah pusat dan Gerakan Aceh Merdeka (GAM) pada 15 Agustus 2005 di Finlandia, Helsinki. Kesempatan ini tidak disia-siakan oleh perempuan Aceh dalam upayanya mengangkat kembali harkat dan martabat perempuan Aceh untuk kembali bangkit mendapatkan hak hidup mereka sebagai perempuan dalam pelbagai bidang terutama dalam bidang sosial, politik, ekonomi dan lain-lain.

Bangkitnya upaya perempuan Aceh pasca konflik dan tsunami untuk mendapatkan dan meraih hak-hak mereka dalam setiap bidang kehidupan bernegara telah menciptakan pelbagai macam upaya serta didukung dengan pelbagai faktor yang menjadi penentu keberhasilan kaum perempuan Aceh terutama dalam persoalan pembangunan kembali hak-hak perempuan Aceh. Berdasarkan hal tersebut, artikel ini akan membahas analisis teoritis gender dan hubungannya dengan pembangunan hak perempuan di Aceh pasca konflik dan tsunami.

\section{TINJAUAN PUSTAKA}

Kajian mengenai perempuan terutama di wilayah konflik telah banyak dilakukan oleh peneliti-peneliti sebelumnya. Seperti kajian yang dilakukan oleh Sentiela Ocktaviana, Widjajanti M. Santoso, dan Dwi Purwoko berjudul “Peran- 
peran Perempuan di Wilayah Konflik: Antara Korban, Penyintas, dan Agen Perdamaian" yang mengkaji peran perempuan di wilayah konflik yaitu di Aceh dan Nusa Tenggara Barat (NTB).

Selama konflik berlangsung di dua wilayah tersebut didapati bahwa kaum perempuan hanya dianggap sebagai korban, padahal upaya informal telah dilakukan oleh kaum perempuan dalam memberikan kontribusi positif pada proses perdamaian, penyintas, maupun inisiator. Akan tetapi hal tersebut dilupakan sehingga perempuan merasa tidak mendapatkan keadilan. Perempuan Aceh korban konflik berharap banyak kepada lembaga Komisi Kebenaran dan Rekonsiliasi Aceh (KKR-Aceh) untuk dapat memenuhi hak perempuan yang selama ini telah dideskreditkan, namun usaha tersebut ternyata gagal.

Lain hal lagi dengan perempuan Ahmadiyah di wilayah NTB yang mengalami kekerasan fisik, psikologi, dan ekonomi yang tidak mendapatkan perhatian dari pemerintah setempat dikarenakan status kewarganegaraan mereka. Segala persoalan mengenai hak-hak perempuan tersebut nyatanya jelas diterangkan dalam CEDAW, Resolusi DK PBB No. 1325, dan Rekomendasi umum PBB No. 19, di mana pemerintah pusat dan daerah memiliki tanggung jawab dalam pemenuhan keadilan dan hak-hak perempuan.

Kajian selanjutnya dilakukan atas kerjasama lembaga Pustaka Larasan, ICAIOS, dan KITLV-Jakarta dalam sebuah kumpulan tulisan yang berjudul "Aceh Pascatsunami dan Pascakonflik" yang disunting oleh Patrick Daly, R. Michael Feener, dan Anthony Reid pada tahun 2012. Kajian ini fokus meneliti mengenai keadaan masyarakat Aceh pasca konflik dan tsunami, di dalamnya termasuk membahas mengenai kondisi perempuan Aceh. Kajian ini dilakukan dengan tujuan untuk membahas sejumlah pelajaran penting tentang rekonstruksi Aceh dan proses perdamaian Aceh pemeliharaan komunitas masyarakat Aceh dan internasional.

\section{METODE PENELITIAN}

Penulisan ini akan membahas mengenai gender dan pembangunan hak perempuan di Aceh pasca konflik dan tsunami. Kajian permasalahan ini melingkupi penggunaan konsep gender dalam memicu kebangkitan pembangunan hak perempuan Aceh paska konflik dan tsunami. Penulisan ini menggunakan tehnik pengumpulan data penelitian kepustakaan yaitu pengumpulan data dilakukan melalui data-data yang diperoleh dari pengumpulan sumber-sumber bacaan yang meliputi buku, jurnal, surat kabar dan lain-lain.

Variabel penelitian dalam penulisan ini ialah genderdan pembangunan perempuan. Penelitian ini menggunakan tehnik analisis yang kualitatif, yaitu penelitian ini menganalisis permasalahan dan menguraikan pembahasan menggunakan kata-kata atau deskriptif. 
Dokumentasi merupakan metode pengumpulan data penguat melalui artikel, arsip-arsip, dan teori-teori yang terdapat dalam buku-buku tertentu yang berkaitan dengan masalah yang diteliti. Dalam hal ini, peneliti akan mengumpulkan berita-berita yang dipublikasikan dalam bentuk artikel yang terkait dengan masalah penelitian untuk kemudian dianalisis.

Analisis data merupakan proses mencari dan menyusun secara sistematis data yang diperoleh baik melalui wawancara, observasi maupun dokumentasi lapangan sehingga data yang diperoleh akan lebih mudah dipahami dan diinformasikan kepada orang lain. Analisis yang dilakukan bertujuan untuk memahami hubungan dan konsep dalam data sehingga hipotesis dapat dikembangkan dan dievaluasi. Teknik analisis dalam penelitian ini bersifat kualitatif yang dilakukan secara interaktif dan berlangsung secara terus menerus sampai tuntas sehingga datanya sudah jenuh.

Langkah yang akan ditempuh dalam penelitian ini meliputi, pertama melakukan penelitian kepustakaan meliputi buku, jurnal maupun surat kabar, setelah data terkumpul akan disusun atau dinarasikan dalam bentuk kalimatkalimat yang lebih tertata. Sebelum dianalisis lebih lanjut dan ditarik kesimpulan, data harus disortir berdasarkan mutu dengan melakukan evaluasi pertama. Setelah evaluasi pertama, maka peneliti akan melengkapi data dengan menggunakan wawancara ulang dengan informan lain untuk memastikan data yang diperoleh sesuai dengan masalah yang diteliti.

Untuk validitas data, peneliti akan menggunakan metode triangulasi, yaitu metode pengecekan terhadap data wawancara yang diperoleh melalui pelbagai sumber dengan membandingkan hasil wawancara antara satu informan dengan informan lainnya. Berdasarkan metode tersebut diharapkan akan mendapatkan kesesuaian yang beruntuk terhadap data yang diperoleh dari setiap informan.

\section{TEMUAN DAN PEMBAHASAN}

\section{A. Gender: Pendekatan Historis dan Teoritis}

Pembahasan mengenai gender telah lama di dominasi pada kehidupan masyarakat Barat, terutama Amerika dan Eropa. Gender sendiri merupakan sebuah pemahaman yang hakekatnya pekat dengan nuansa barat (western invention) (Connell, 1993), di mana isu gender sebagai upaya untuk mencapai kesamaan antara perempuan dan laki-laki pertama kali muncul pada tahun 1950 dan 1960-an.

Gerakan kaum perempuan ini muncul sebagai sebuah konflik sosial yang dilatarbelakangi dengan tujuan untuk mendobrak sistem patriarchy yang dilindungi oleh kuatnya tradisi struktural fungsional dalam sistem sosial di tengah-tengah masyarakat. Kuatnya sistem patriarchy yang terdapat 
dalam sebuah keluarga cenderung menyebabkan munculnya ketimpangan gender terutama dalam persoalan ekonomi.

Gerakan gelombang pertama kaum perempuan lebih kepada gerakan filsata di Eropa yang dipelopori oleh Lady Mary Wortley Montagu dan Marquis de Condorcet tahun 1785. Sedangkan gelombang kedua dimulai pada tahun 1960 yang ditandai dengan berlakunya liberalisme gaya baru melalui diikutsertakannya perempuan dalam hak suara di parlemen (Herien Puspitawati, 2013).

Konsep gender pada dasarnya bertentangan dengan konsep sex yang mana kedua pertentangan ini belum begitu familiar hingga diperkenalkan pada tahun 1970-an. Robert Stoller yang merupakan seorang pakar psikologi merupakan orang pertama mengangkat isu mengenai perbedaan antara gender dan sex (Margaret Simmonds, 2012). Perdebatan mengenai hal tersebut terus berkembang menjadi sebuah kajian yang memfokuskan perbedaan antara konsep gender dengan konsep sex secara lebih terstruktur, di mana gender merupakan salah satu konsep utama bagi lahirnya gerakan kaum perempuan.

Pembahasan mengenai gender dalam dunia global telah mencetuskan sebuah gerakan kaum perempuan dunia yang menyebar hingga seluruh lapisan yang berupaya untuk menuntut hak-hak perempuan terutama dalam persoalan pembangunan. Pelbagai gerakan perempuan dunia telah banyak mencetuskan isu-isu global yang pada dasarnya bertujuan untuk menciptakan peran perempuan yang lebih aktif dalam proses pembangunan seperti yang terdapat dalam International on Population and Development (1994) dan pada Konferensi Puncak Wanita Sedunia (1995).

Sejarah gender pertama kali berkembang dalam konteks dunia Barat, terutama peristiwa yang terjadi pada 12 Juli 1963 yang ditandai dengan munculnya gerakan global yang dipelopori oleh gerakan kaum perempuan.Gerakan ini telah mempelopori suatu resdusi melalui Badan Ekonomi dan Sosial PBB (ECOSOC) pada tahun 1967 yang kemudian terbentuklah Commission on The Status of The Women yang secara khusus memperhatikan status dan isu-isu yang berkaitan dengan kaum perempuan.

Perhatian yang diberikan PBB terhadap kaum perempuan tersebut kemudian diintensifkan lagi melalui pelbagai konferensi dunia yang khusus dilaksanakan untuk membahas mengenai isu-isu kaum perempuan. Konferensi perempuan dunia pertama kali diadakan di Mexico City pada tahun 1975 yang menekankan peran perempuan pada Women in Development (WID), yaitu pembahasan mengenai integrasi perempuan di bidang pembangunan yang berfokus pada produktivitas kaum perempuan.

WID dianggap tidak mampu untuk memenuhi segala tuntutan kaum perempuan sehingga terbentuklah Women and Development (WAD) yang dicetuskan oleh kaum feminis-marxis yang pada tahun 1979 menghasilkan 
Convention on The Elimination of All Forms of Discrimination Against Women (CEDAW). CEDAW pada tahapan selanjutnya menjadi pedoman bagi banyak negara di dunia sebagai dasar untuk memberikan kesetaraan dan persamaan hak kaum perempuan dalam segala bidang kehidupan bernegara.

Pemenuhan terhadap hak kaum perempuan sedunia yang dirasa belum efektif dan efesien menyebabkan WAD digantikan dengan Gender and Development (GAD) yang dirasa lebih memenuhi kualifikasi kebutuhan akan hak-hak kaum perempuan global yang menitikberatkan kepada prinsip hubungan kemitraan dan keharmonisan antara perempuan dan laki-laki. Konsep GAD ini kemudian dikuatkan lagi dengan dilaksanakannya The International Conference on Population and Development (ICPD) di Kairo pada tahun 1994.

Pembahasan dan perdebatan mengenai gender semakin populer manakalah isu gender menjadi fenomena global terutama yang berkaitan dengan kebijakan pembangunan, sehingga PBB melalui Konferensi Perempuan di Beijing pada 1995 semakin mengangkat persoalan gender ke dalam isu-isu global. Empat isu utama yang diangkat dalam konferensi ini ialah mengenai kesetaraan gender, keadilan gender, pemberdayaan perempuan dan integrasi kependudukan ke dalam kebijakan pembangunan dan program penghapusan kemiskinan.

Perkembangan isu-isu gender kemudian menjadi pembahasan yang menarik dikalangan ilmuwan terutama ilmuwan sosiologi. Secara sosiologis, gender dipandang sebagai konsep yang terdiri dari konsep-konsep pendukung lainnya, hal ini seperti yang terdapat dalam kajian yang ditulis oleh Linda L. Lindsey (2005) dalam bukunya yang berjudul "The Sociology of Gender: Theoretical Perspectives and Feminist Frameworks" yang secara garis besar menekankan kepada empat konsep dalam sosiologi gender, yaitu stereotypes, sexism, patriarchy, dan androcentrism.

Konsep stereotypes populer pada tahun 1922 melalui kajian yang dilakukan oleh Lippman untuk menggambarkan "typical picture" yaitu sebuah pemikiran tentang hubungan kelompok sosial. Stereotypes diartikan sebagai sebuah metodologi untuk memahami pengelompokkan kerja individu menjadi kategori kelompok (Jane Pilcher \& Imelda Whelehan, 2004), artinya dalam memahami sebuah fenomena sosial bukan lagi didasarkan kepada penilaian individu tetapi lebih kepada penilaian secara kelompok yaitu kelompok laki-laki dan perempuan.

Konsep stereotypes secara rinci merupakan konsep yang menyatakan bahwa masyarakat menempati pembagian status (gap) yang memiliki pembeda dari ciri-ciri yang utama. Pembedaan ciri ini walaupun tidak selalu dipandang negatif namun berhasil menciptakan sebuah perlawanan terhadap terjadinya diskriminasi yang didasari atas perbedaan ciri terutama 
ciri yang dimiliki antara kaum laki-laki dengan ciri yang dimiliki oleh kaum perempuan khususnya perbedaan secara biologis.

Penempatan konsepstereotypes yang negatif dapat mewujudkan sexism, yaitu sebuah paham yang meyakini bahwa status perempuan lebih rendah dibandingkan dengan status laki-laki. Kaum laki-laki tidak kebal terhadap konsekuensi negatifdari konsep sexism, tetapi kaum perempuan lebih mungkin mengalaminya dikarenakan status yang mereka miliki lebih terstigma daripada status yang dimiliki oleh kaum laki-laki (Linda L. Lindsey, 2005).

Konsep sexism memberikan peluang bagi munculnya rasa diskriminasi oleh kaum perempuan terhadap kaum laki-laki. Anggapan yang menyatakan bahwa kedudukan kaum perempuan lebih rendah dibandingkan kedudukan kaum laki-laki telah menyebarkan risiko negatif terhadap keseimbangan peran antara kaum perempuan dan kaum laki-laki terutama dalam persoalan pembangunan.

Kepercayaan yang berlebihan terhadap sifat dan hak yang rendah secara biologis terhadap kaum perempuan telah memperkuat terjadinya diskriminasi keadilan bagi hak-hak yang seharusnya diperoleh kaum perempuan. Meningkatnya keyakinan dan pandangan sebagian besar masyarakat terhadap sexism akan mengabadikan konsep patriarchy yang semakin menguatkan berlakunya bias gender dalam pembangunan.

Konsep patriarchy merupakan sebuah konsep yang menerangkan dominasi laki-laki dalam kepemimpinan struktur sosial yang menekan kaum perempuan. Dominasi laki-laki terhadap kaum perempuan dalam kepemimpinan pada struktur sosial terutama dalam sebuah negara menyebabkan kemandulan dari peran perempuan atas keikutsertaannya untuk melakukan pembangunan.

Walby (1990) mendefinisikan patriarchy sebagai sistem struktur dan praktik sosial yang mana laki-laki mendominasi, menekan, dan mengeksploitasi perempuan. Walby turut memperkenalkan 6 struktur dari konsep patriarchy yaitu produksi rumah tangga, imbalan kerja, negara, kekerasan oleh laki-laki, seksualitas, dan budaya di mana kesemuanya setuju untuk lebih mendalam, menyebarkan dan mengaitkan dengan subordinasi kaum perempuan (Jane Pilcher \& Imelda Whelehan, 2004).

Konsep patriarchy menyumbangkan kesempatan bagi kaum laki-laki untuk semakin merasa lebih berkuasa atas hak-hak yang seharusnya juga dimiliki oleh kaum perempuan. Konsep patriarchy secara definisi memperkenalkan sebuah konsep lainnya, yaitu androcentrism, yaitu sebuah norma yang memusatkan kinerja laki-laki diseluruh lembaga sosial yang menjadi standar untuk dipatuhi oleh semua orang (Linda L. Lindsey, 2005).

Penggabungan daripada keempat konsep tersebut memberikan penguatan bagi berlakunya konsep gender yang diatur berdasarkan 
penentuan secara biologis dan hal tersebut tidak dapat dirubah. Namun, hal ini bertentangan dengan beberapa pakar gender lainnya yang menyatakan bahwa gender bukanlah melihat dari perbedaan secara biologis, tetapi berdasarkan perbedaan secara sosial-budaya. Pemahaman yang lebih mendalam mengenai gender akan dibahas melalui perspektif sosiologis yang terdiri dari perspektif struktural-fungsional, perspektif teori konflik,dan perspektif feminisme.

Perspektif struktural-fungsional merupakan teori umum dalam bidang sosiologi yang menekankan kepada anggapan bahwa masyarakat berada dalam keadaan yang stabil serta merupakan satu kesatuan yang terdiri dari bagian-bagian dan saling mempengaruhi. Teori ini menganalogikan masyarakat seperti tubuh manusia (organicism).

Emile Durkheim (1857-1917) merupakan salah satu ahli dalam teori ini yang menyatakan bahwa apabila terdapat keperluan tertentu dalam sebuah masyarakat tetapi tidak dipenuhi maka akan menyebabkan patologi yang menyebabkan hancurnya sistem politik. Patologis menunjukkan keadaan yang tidak seimbang atau perubahan sosial, namun apabila keadaan dianggap normal atau seimbang maka dikenal sebagai equilibrium.

Struktural fungsional mengakuai adanya keberagaman dan perbedaan dalam kehidupan sosial masyarakat yang dapat menyebabkan berlakunya pelbagai macam risiko seperti perbedaan struktur, status, peran dan lain sebagainya dalam sebuah sistem. Oleh karena itu, pelbagai perbedaan yang disebabkan tersebut diakui dan dianggap penting oleh para fungsionalis sebagai bagian dari keseimbangan sosial, termasuk di dalamnya nilai yang berkaitan dengan peran gender.

Peran gender dalam perspektif fungsionalis ini di bagi kedalam dua periode, yaitu periode preindustrial society and contemporary society. Pada periode preindustrial society, para fungsionalis menekankan bahwa terdapat perbedaan yang cukup mendasar dari keseimbangan sosial pada masyarakat pra-industri yang ditandai adanya penetapan tugas yang berbeda antara laki-laki dan perempuan. Laki-laki bertugas untuk berburu mencari makanan sedangkan perempuan memiliki peran untuk mengandung, melahirkan dan merawat anak serta melakukan pekerjaan rumah tangga lainnya. Sedangkan periode contemporary society, spesialisasi tugas rumah tangga berdasarkan gender lebih disfungsional daripada fungsional di mana kaum perempuan yang cenderung merasa tidak bahagia dengan perannya dalam mengurus rumah tangga lebih memungkinkan untuk melakukan kegiatan lain di luar urusan rumah tangga.

Perspektif struktural-fungsional ini mendapat kritik dari kaum feminisme yang menekankan bahwa perspektif struktural-fungsional mengakui adanya pembagian peran dan status sosial berdasarkan jenis kelamin yang menyebabkan terpisahnya peran perempuan dalam urusan 
publik maupun privat. Pada sisi lain, terlepas daripada kritik yang diberikan terhadap teori ini dalam memandang gender, struktural-fungsional tetap dipertahankan dalam sistem sosial masyarakat terutama dalam pembagian kerja yang berbasis jenis kelamin.

Perspektif teori konflik merupakan sebuah pandangan yang melihat bahwa masyarakat yang terdiri dari pelbagai entitas akan selalu diwarnai oleh konflik terutama yang dilatarbelakangi oleh keterbatasan dan alokasi sumber daya. Teori konflik muncul dari pemikiran yang dituangkan oleh Engels dan Marx mengenai kelas sosial.

Karya Karl Marx (1818-1883) menyatakan bahwa teori konflik ini yang berbasiskan asumsi bahwa masyarakat merupakan panggung untuk memperjuangkan kekuasaan dan dominasi untuk melawan kelompok maupun individu yang mendominasi sumber daya. Sedangkan Friedrich Engels (1820-1895) serupa dengan Marx, menyatakan bahwa dalam masyarakat kontemporer,keluarga merupakan sistem sosial yang didalamnya terdapat pelbagai konflik dan tidak memiliki harmoni. Engels mendukung adanya peran komplementer, khusus dan saling tumpang tindih yang menguntungkan dalam sebuah keluarga.

Perspektif teori konflik dalam menilai konsep gender lebih berfokus kepada kekuatan ekonomi, terutama berpatokan kepada penempatan sosial dari sebuah keluarga yang terlahir dengan tingkat ekonomi yang tinggi atau rendah. Teori ini mendapatkan kritik dari segi penyebab konflik yang diyakini tidak hanya dilatarbelakangi oleh faktor ekonomi tetapi juga adanya ketegangan antara suami dan istri, orang tua dan anak, maupun antara anak dan anak. Selepas dari kritik tersebut, teori konflik berhasil memicu munculnya teori-teori baru seperti feminism, liberal feminism, maupun marxis-sosialis feminism.

Persepektif selanjutnya ialah perspektik feminisme yang bersesuaian dengan teori konflik, di mana keduanya menyatakan bahwa struktur ketimpangan sosial dipertahankan oleh ideologi-ideologi yang diterima oleh kaum laki-laki dan kaum perempuan mengenai keistimewaan maupun penindasan yang diperankan oleh mereka. Secara khusus, teori feminisme mengajukan kerangka pemikiran bagi kaum perempuan dalam upayanya untuk mengubah status sosial kaum perempuan dari segala sektor kehidupan seperti sosial, politik, ekonomi dan lain-lain.

Huraian mengenai sejarah dan pelbagai perspektif dalam memandang gender telah melahirkan ragam definisi daripada gender itu sendiri. Banyak publik yang seringkali salah menyamakan definisi gender dengan sex (jenis kelamin), hal ini sebenarnya sesuai dengan definisi yang terdapat dalam Kamus Bahasa Inggris yang mengartikan gender dengan sex (jenis kelamin).

Gender memiliki pengertian yang lebih kompleks daripada hanya sekedar sex (jenis kelamin), atau dapat dikatakan bahwa gender berbeda 
dengan sex (jenis kelamin). Gender merupakan identifikasi perbedaan antara kaum laki-laki dan kaum perempuan yang didasarkan kepada segi sosialbudaya, sedangkan sex (jenis kelamin) merupakan identifikasi bagi kaum laki-laki dan kaum perempuan dari segi anatomi biologis.

Gender didefinisikan sebagai perbedaan antara laki-laki dan perempuan dalam peran, fungsi, hak, tanggung jawab dan perilaku yang dibentuk oleh tata nilai sosial, budaya dan adat istiadat dari kelompok masyarakat yang dapat berubah menurut waktu serta kondisi setempat (Herien Puspitawati, 2013). Definisi ini menegaskan bahwa gender merupakan perbedaan yang identik dengan peran yang masing-masing dimiliki oleh kaum laki-laki dan kaum perempuan.

Tidak sebatas pada perbedaan peran antara kaum laki-laki dan kaum perempuan, gender juga disandingkan dengan institusi sosial. Hal ini dinyatakan oleh Smith (1987) dan West \& Zimmerman (1987) bahwa gender merupakan suatu set hubungan yang nyata dalam institusi sosial dan dihasilkan kembali dari interaksi antar personal (Lloyd, 2009). Gender terbentuk dari adanya hubungan antara laki-laki dengan perempuan dalam suatu sistem sosial melalui interaksi yang mereka lakukan.

Definisi gender juga hadir sebagai hasil dari ideologi-ideologi yang dibentuk oleh masyarakat. Butler (1990) menyatakan pada tingkat ideologi, gender dihasilkan (Lloyd, 2009) dan Smith (1987) juga menyatakan bahwa teori gender merupakan suatu pandangan tentang konstruksi sosial yang sekaligus mengetahui ideologi dan tingkatan analisis material (Lloyd, 2009).

Gender tidak selalu berbicara mengenai peran-peran yang dimiliki oleh kaum laki-laki dan kaum perempuan saja. Secara sinergis, gender dapat disimpulkan sebagai perbedaan antara kaum laki-laki dan perempuan yang tidak hanya didasarkan kepada perbedaan biologis dan sosiologis tetapi gender merupakan sebuah konstruksi konsep yang lebih kompleks untuk mengkaji hubungan keseimbangan peran, fungsi, tanggung jawab dan hak antara laki-laki dan perempuan atas dasar perbedaan yang dimiliki dalam pelbagai sektor kehidupan bernegara.

\section{B. Gender dan Pembangunan Perempuan di Aceh}

Tantangan utama perempuan Aceh pasca konflik berkepanjangan hampir tiga dekade antara Gerakan Aceh Merdeka (GAM) dengan pemerintah Republik Indonesia yang berujung pada perundingan damai di Helsinki, Finlandia pada 15 Agustus 2005 serta bencana gempa dan tsunami yang melanda Aceh pada 26 Desember 2004 merupakan awal transisi bagi kestabilan pembangunan khususnya bagi perempuan Aceh. Perdamaian dan rencana pembangunan kembali kehidupan masyarakat Aceh dari pelbagai bidang seperti ekonomi, politik maupun sosial tidak terlepas dari perbincangan terhadap hak-hak kaum perempuan. 
Pembahasan mengenai hak kaum perempuan Aceh tidak terlepas dari hak perempuan dalam pembangunan. Pembangunan perempuan dalam konteks ini menitikberatkan kepada upaya peningkatan peran dan kedudukan perempuan Aceh dalam pelbagai bidang kehidupan dengan tujuan untuk menciptakan keadilan dan kesetaraan antara kaum laki-laki dan kaum perempuan.

Seringkali kaum perempuan hanya diidentikkan dengan tugasnya sebagai ibu rumah tangga yang tentunya menyebabkan terbatasnya ruang bagi partisipasi kaum perempuan yang berakhir kepada munculnya ketidaksetaraan dan ketidakadilan gender. Apabila pemikiran tersebut terus dikekalkan maka kaum perempuan akan menghadapi tantangan yang lebih berat untuk ikut serta dalam proses pembangunan.

Proses pembangunan pada era modern ini telah banyak melibatkan kaum perempuan sebagai bagian dalam pengambilan kebijakan publik, yang artinya kaum perempuan memiliki hak dan aktif untuk turut memikirkan persoalan kehidupan bernegara terutama yang berkaitan dengan peran dan hak kaum perempuan itu sendiri yang dapat memberikan pandangan bagi terwujudnya kesetaraan dan keadilan antara hak kaum laki-laki dan kaum perempuan terutama dalam pembangunan. Pembangunan kaum perempuan tidak hanya terbatas bagi pemenuhan hak, peran maupun tanggun jawab yang seharusnya dilakukan oleh kaum perempuan untuk mendapatkan tempat dalam setiap pengambilan keputusan publik, namun pembangunan perempuan khususnya di Aceh juga sebaiknya ditempatkan pada posisi-posisi strategis seperti dalam lembaga politik dan sosial yang lebih banyak menyediakan kesempatan bagi kaum perempuan dalam menunjukkan eksistensinya dan memberikan sumbangsihnya bagi pembangunan daerah.

Pentingnya pembahasan mengenai perempuan Aceh dalam pembangunan adalah untuk menganalisis proses dan kemajuan pembangunan di Aceh baik dalam bidang sosial, politik dan ekonomi. Selain itu, banyaknya perempuan Aceh yang mengalami kekerasan pada masa konflik juga akan mempengaruhi proses dan kemajuan pembangunan perempuan di Aceh pasca tsunami dan pasca konflik.

Pembahasan mengenai gender dan ekonomi selalunya menjadi hal yang menarik, manakala di Indonesia khususnya Aceh dengan budaya patriarki yang telah mengakar kuat dalam setiap aspek kehidupan termasuk ekonomi, laki-laki selalu ditempatkan sebagai tulang punggung keluarga. Sedangkan perempuan diidentikkan dengan pekerjaan rumah tangga yaitu mengurus rumah, anak dan suami. Namun, konsep gender melalui penyetaraan gender telah membuka peluang bagi perempuan Aceh untuk melakukan kegiatan diluar rumah salah satunya ialah ikut serta dalam upaya pemenuhan ekonomi. 
Perempuan Aceh pasca konflik dan pasca tsunami nyatanya tidak mudah untuk mendapatkan keadilan dan kesetaraan dalam perekonomian. Hal ini dikarenakan, pasca konflik dan tsunami Aceh, perempuan diposisikan bergantung kepada suami atau laki-laki dalam keluarganya. Hal ini terjadi karena perempuan Aceh pada masa transisi kesulitan mendapatkan pekerjaan yang sesuai serta pekerjaan perempuan hanya dianggap sebagai pekerjaan sampingan.Namun, pada tahun 2016 jumlah pekerja perempuan Aceh semakin meningkat, hal ini terjadi dikarenakan keterbukaan masyarakat serta beberapa sistem perekonomian yang mulai membidik kemampuan dan keahlian perempuan dalam bekerja sebagai faktor penting dalam upaya pembangunan ekonomi daerah, hal ini sesuai dengan grafik Badan Pusat Statistik Aceh tahun 2016.

Gambar. 1 Persentase Penduduk Aceh yang Bekerja menurut Jam Kerja dan Jenis Kelamin, Februari 2016.

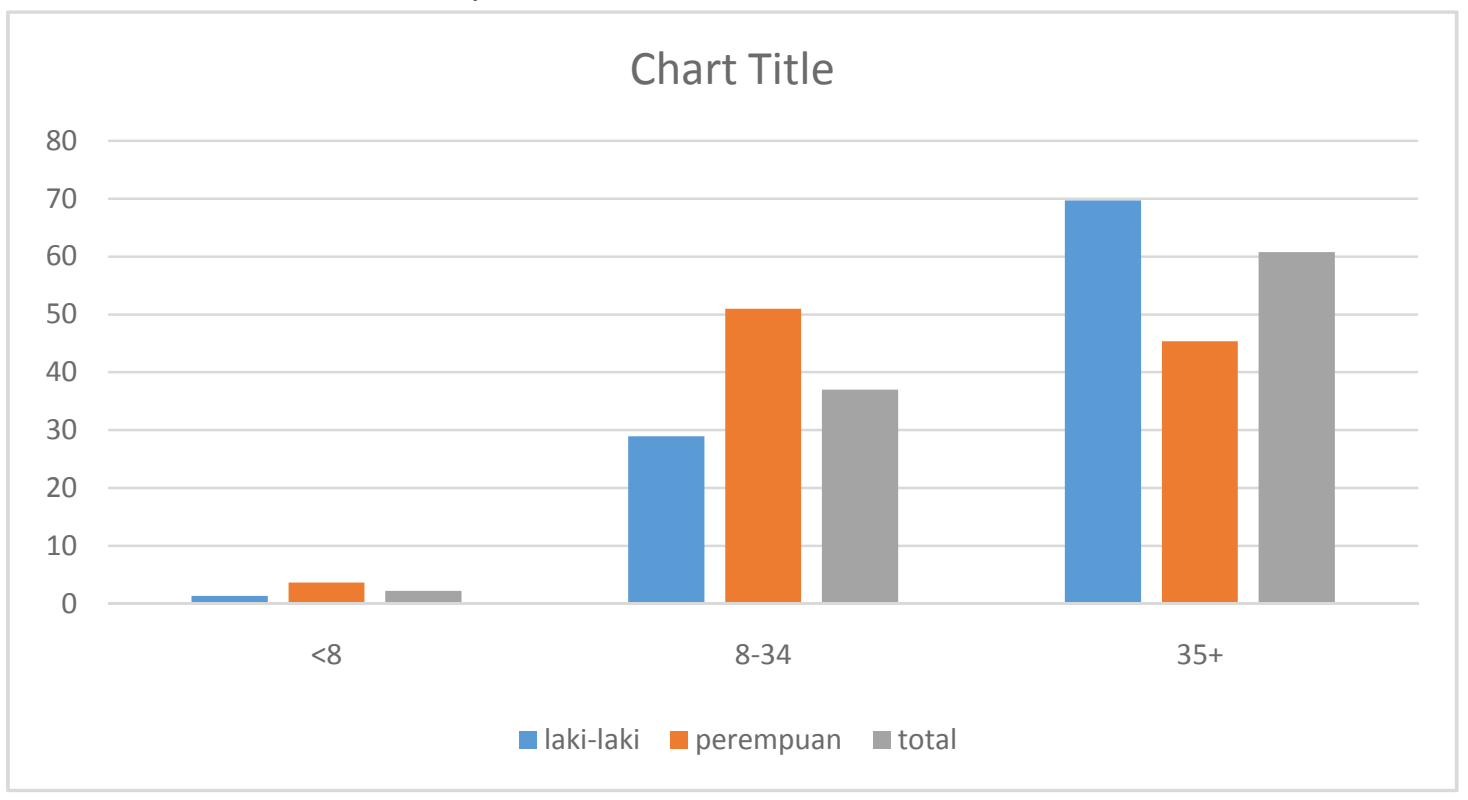

Sumber: Berita Resmi Statistik No. 24/05/TH.XIX, 4 Mei 2016

Peningkatan persentase kaum perempuan sebagai pekerja di Aceh memberikan gambaran nyata bahwa bagi Aceh yang sedang membenahi diri menjadi lebih mapan terutama pasca konflik dan tsunami telah berupaya untuk menciptakan keadilan dan kesetaran gender bagi kaum perempuan Aceh dalam bidang ekonomi. Hal ini sesuai dengan ketetapan yang terdapat dalam CEDAW yang salah satunya menyatakan penghapusan segala bentuk diskriminasi terhadap perempuan.

Aceh telah membuktikan, bahwa konflik dan bencana alam tidak menghalangi upaya pemerintah Aceh untuk memberikan hak dan mengembalikan harkat martabat perempuan Aceh yang sudah sedari 
zaman penjajahan dikenal telah ikut serta dan berperan dalam urusan publik sebut saja dengan hadirnya Cut Nyak Dhien, Laksamana Malahayati, Cut Mutia, dan lain-lain. Di zaman modern ini, hak perempuan Aceh juga terus diperjuangkan, dalam segi ekonomi yaitu dengan dibukanya kesempatan bagi kaum perempuan untuk bekerja dan mendapatkan penghasilan secara layak yang terus diupayakan oleh pelbagai kalangan.

Kondisi perempuan Aceh pasca konflik dan tsunami di bidang sosial seperti kesehatan dan pendidikan sangat mengkhawatirkan. Di Awal tahun 2006, penemuan oleh Aceh Recovery Forum mencatat 134 angka kematian bayi dan 54 kematian ibu melahirkan di pengungsian. Hal ini dikarenakan sulitnya kaum perempuan untuk mengakses sarana dan prasarana kesehatan yang tersedia, seperti minimnya transportasi dan tenaga kesehatan di daerah-daerah (Gender Working Group, 2007).

Awal masa transisi Aceh pasca konflik dan tsunami, pembangunan kesehatan bagi kaum perempuan di Aceh masih menunjukkan minimnya upaya pemerintah untuk melindungi hak-hak kaum perempuan di bidang kesehatan. Namun, pemenuhan dari hak-hak kaum perempuan untuk mendapatkan keadilan dan kesetaraan dalam setiap pembangunan selalu menjadi prioritas pemerintah Aceh dari tahun ke tahun, hal ini tergambar dari meningkatnya sasaran program pembangunan kesehatan bagi kaum perempuan di Aceh apda tahun 2015.

Gambar 2. Perempuan Sasaran Program Pembangunan Kesehatan Aceh Tahun 2015

\begin{tabular}{|l|l|l|}
\hline \multicolumn{1}{|c|}{ Sasaran Program } & \multicolumn{1}{c|}{ Formula } & \multicolumn{1}{c|}{ Jumlah Perempuan } \\
\hline Lahir Hidup & - & - \\
\hline Bayi & 0 Tahun & 56.347 \\
\hline Batita & 0-2Tahun & 167.824 \\
\hline Anak Balita & 1-4Tahun & 220.958 \\
\hline Balita & $0-4$ Tahun & 277.305 \\
\hline Pra Sekolah & 5-6 Tahun & - \\
\hline Anak Usia Kelas 1 SD/setingkat & 7 Tahun & 51.196 \\
\hline Anak Usia SD/setingkat & 7-12 Tahun & 292.969 \\
\hline Penduduk Usia Muda & $<15$ Tahun & 770.357 \\
\hline Penduduk Usia Produktif & 15-64 Tahun & 1.624 .120 \\
\hline Penduduk Usia Lanjut & $\geq 60$ Tahun & 169.572 \\
\hline Penduduk Usia Lanjut Risiko Tinggi & $\geq 70$ Tahun & 66.665 \\
\hline Wanita Usia Subur & 15-49 Tahun & - \\
\hline Wanita Usia Subur Imunisasi & 15-39 Tahun & - \\
\hline Ibu Hamil & $1,1 \times$ Lahir Hidup & - \\
\hline Ibu Bersalin/nifas & $1,05 x$ lahir hidup & - \\
\hline
\end{tabular}

Sumber: Profil Kesehatan Aceh Tahun 2015 
Pembangunan kesehatan perempuan Aceh terus menjadi fokus pemerintah untuk mewujudkan kesetaraan dan keadilan gender di Aceh. Pertimbangan bahwa pada masa konflik juga tsunami, perempuan Aceh paling banyak mengalami intimidasi maupun kekerasan menjadikan fokus terhadap kesehatan perempuan Aceh sebagai salah satu prioritas pemerintah dalam meningkatkan pembangunan kesehatan kaum perempuan.

Pembangunan perempuan di bidang pendidikan pada awal transisi masih diwarnai dengan alasan-alasan ekonomi dan sosio-kultural yang menyebabkan tingkat pendidikan kaum perempuan Aceh sangat rendah dibandingkan dengan kaum laki-laki. Namun saat ini, jumlah perempuan yang menuntut ilmu di pelbagai lembaga-lembaga pendidikan sudah meningkat secara signifikan.

Peningkatan jumlah perempuan yang menempuh pendidikan di pelbagai lembaga pendidikan tercermin dari ketiadaan kuota atau aturan yang membatasi jumlah kaum perempuan untuk mendapatkan pendidikan. Selain itu, prinsip sosio-kultural yang mulai menipis tergerus globalisasi telah membuka peluang bagi perempuan untuk lebih leluasa mengenyam pendidikan.

Pembangunan politik merupakan salah satu aspek kajian untuk melihat keterlibatan gender dalam pengambilan keputusan seringkali dianggap sebagai tolak ukur utama. Pembangunan politik perempuan Aceh pada masa awal pasca konflik dan tsunami sama sekali tidak tersentuh oleh kaum perempuan, basis pemerintahan dan politik dikuasai seluruhnya oleh kaum laki-laki.

Pembangunan perempuan dalam bidang politik pertama kali muncul dilatarbelakangi dengan hadirnya organsiasi perempuan Aceh yaitu LINA (Lembaga Inong Aceh). LINA saat ini dikenal sebagai salah satu LSM yang bergerak di bidang perempuan untuk merespon kondisi faktual tentang kehidupan kaum perempuan eks-kombatan yang belum mendapatkan ruang beruntung dan posisi sosial pasca konflik (Anna Christi Suwardi, 2015). Seterusnya LINA tidak hanya berfokus kepada permasalahan perempuan eks-kombatan saja, tetapi hingga saat ini LINA telah menjelma sebagai salah satu LSM yang aktif mengupayakan kesetaraan dan keadilan gender bagi seluruh perempuan Aceh salah satunya dengan membangun motivasi terhadap partisipasi perempuan Aceh dalam politik.

Tingkat partisipasi perempuan Aceh dalam politik juga semakin terlihat dari keikutsertaan perempuan Aceh dalam ajang Pemilihan Umum (Pemilu) baik pemilu legislatif maupun pemilihan kepala daerah. Walaupun kuota 30\% keterwakilan perempuan dalam parlemen Aceh tidak terpenuhi, namun hal tersebut turut menunjukkan bahwa pemerintah Aceh 
membuka peluang bagi kaum perempuan untuk turut serta dalam pesta demokrasi baik sebagai pemilih maupun sebagai calon yang dipilih.

Pembangunan politik perempuan Aceh dibandingkan dengan pembangunan ekonomi dan sosial adalah yang paling rendah. Hal ini terjadi dikarenakan pelbagai faktor seperti pandangan bahwa politik itu kotor, keterbatasan informasi dan pemahaman tentang isu-isu sosial politik, perasaan rendah diri, ketidakmampuan perempuan berperan ganda, keterbatasan sumber daya ekonomi dan perasaan tidak dapat merepresentasikan kepentingan kaum perempuan (Sri Lestari Wahyuningroem, 2008).

Berdasarkan pelbagai faktor tersebut, didapati bahwa kaum perempuan Aceh masih memiliki keterbatasan untuk memaksimalkan hakhak mereka dalam pembangunan politik di Aceh.Namun, tidak berarti bahwa perempuan Aceh tidak peduli terhadap pembangunan politik, karena meskipun tidak banyak perempuan Aceh yang turut aktif dalam bidang politik Aceh, usaha dan upaya untuk mendapatkan serta mendorong perempuan Aceh lebih aktif terus digalakan oleh pelbagai pihak dari masa ke masa.

\section{KESIMPULAN}

Gender dari pelbagai perspektif diartikan sebagai perbedaan antara kaum laki-laki dan kaum perempuan bukan berdasarkan kepada segi biologis (sex/jenis kelamin), namun gender merupakan perbedaan yang didasarkan kepada aspek sosial-budaya seperti perbedaan peran, fungsi, tanggung jawab dan lainnya. Pelbagai persepektif dari para pakar turut mewarnai keragaman dari konsep gender itu sendiri, terlepas dari perbedaan yang disuguhkan oleh pelbagai perspektif yang ada secara sosiologis, konsep gender merupakan konsep yang sesuai untuk terus digunakan dalam mengupas persoalanpersoalan yang berkaitan antara hak kaum perempuan dan kaum laki-laki, salah satunya dalam persoalan pembangunan.

Persoalan pembangunan yang melibatkan kaum perempuan merupakan pembahasan yang menarik terutama dalam konteks pembangunan perempuan pada daerah-daerah rawan konflik yang cenderung paling banyak mengalami kekerasan dan intimidasi. Selain itu, daerah pasca bencana juga turut memperkaya kajian terhadap persoalan pembangunan kembali hak-hak perempuan setelah mengalami trauma untuk tetap bangkit dan melangsungkan aktivitas yang lebih bermanfaat.

Aceh sebagai daerah pasca konflik dan tsunami memberikan banyak pelajaran bagi dalam menggambarkan upaya dan usaha yang dilakukan oleh pemerintah Aceh untuk menyesuaikan dan menyeimbangkan antara keadilan dan kesetaraan gender dengan persoalan pembangunan, terutama sekali berkaitan dengan pembangunan hak perempuan di Aceh. Di bidang ekonomi 
dan sosial, pembangunan terhadap hak-hak kaum perempuan Aceh pasca konflik dan tsunami terus mengalami peningkatan yang signifikan ditunjukkan melalui pelbagai upaya pemerintah yang terus meningkatkan program ekonomi dan sosial yang melibatkan perempuan, sedangkan di bidang pembangunan politik, hak kaum perempuan telah diupayakan untuk mendapatkan keadilan dan kesetaraan namun beberapa faktor seperti terbatasnya sumber daya ekonomi menjadi penghambat bagi peningkatan pembangunan politik perempuan di Aceh.

\section{DAFTAR PUSTAKA}

\section{$\underline{\text { Buku }}$}

Butler, J. 1990. Gender Trouble: Feminism and the Subversion of Identity. London: Routledge.

Daly, R. Patrick et al. 2012. Aceh Pascatsunami dan Pascakonflik. Jakarta: KITLV.

Lindsey, Linda L. 2005. Gender Roles: A Sociological Perspective. Upper Saddie River, N. J: Pearson Prentice Hall.

Lloyd, S et al. 2009. Handbook of Feminist Family Studies. Thousand Oaks, CA: Sage.

Pilcher, Jane\& Imelda Whelehan. 2004. Fifty Key Concepts in Gender Studies. London: Sage Publications.

Walby, S. 1990. Theorising Patriarchy. Oxford: Blackwell.

\section{Jurnal}

Anna Christi Suwardi. 2015. Peran Gerakan Perempuan dalam Reintegrasi Perempuan Eks-Kombatan Pasca Konflik: Studi Atas Liga Inong Aceh (LINA). Universitas Gadjah Mada.

Herien Puspitawati. 2013. Konsep, Teori dan Analisis Gender. Institut Pertanian Bogor.

Sentiela Ocktaviana, Widjajanti m. Santoso, dan Dwi Purwoko. 2014. Peranperan Perempuan di Wilayah Konflik: Antara Korban, Penyintas, dan Agen Perdamaian. Jurnal Masyarakat \& Budaya, Volume 16 No. 3 Tahun 2014.

Smith, N. 1987. Dangers of the Empirical Turn. Antipode, 19/1: 59-68.

West, C \& Zimmerman. 1987. Doing Gender. Gender and Society. I. 125-151

\section{Makalah dan Berita}

Sri Lestari Wahyuningroem. 2008. Seri Makalah Diskusi:Meningkatkan Partisipasi Perempuan dalam Politik Aceh: Tantangan dan Peluang. Bangkok: UNIFEM 
Community: Volume 3, Nomor 1, April 2017

ISSN: 2477-5746

Berita Resmi Statistik No. 24/05/TH. XIX, 4 Mei 2016.

Gender Working Group. 2007. Evaluasi Situasi Perempuan Tahun 2006 di Aceh. Profil Kesehatan Aceh Tahun 2015.

Simmonds, Margaret. 2012. Feminist Gender Theory Summary. 